\title{
THE CONFLICTS FACED BY SARA FITZGERALD AS SEEN IN JODY PICOULT'S NOVEL MY SISTER'S KEEPER
}

\author{
Indri Larassanti
}

\begin{abstract}
ABSTRAK
Tujuan utama dari penelitian ini adalah untuk menyelidiki konflik yang dihadapi oleh Sara Fitzgerald dalam sebuah novel laris berjudul My Sister's Keeper karya Jodi Picoult. Penelitian ini juga bertujuan untuk menunjukkan bagaimana konflik pada Sara Fitzgerald berkembang.

Penelitian ini menggunakan pendekatan obyektif untuk membantu menemukan konflik pada Sara Fitgerald dan bagaimana konflik tersebut berkembang dengan menerapkan teori konflik internal dan teori konflik eksternal serta teori frustasi. Data utama yang digunakan adalah novel My Sister's Keeper. Data pendukungnya adalah buku-buku yang membahas teori konflik internal, teori internal serta artikel dari internet.

Hasil penelitian menunjukkan ada empat masalah utama yang mengarah pada Sara Fitzgerald dalam menghadapi konflik tertentu seperti, ketika Sara memiliki anak lagi, Jesse dan Anna merasa terabaikan, persidangan serta kematian Anna. Teori konflik internal dan teori konflik external yang digunakan dalam penilitian ini menunjukkan bagaimana Sara membuat keputusan-keputusan penting untuk menyelamatkan hidup Kate. Sara banyak menghadapi kegagalan akibat dari keputusan yang ia ambil dan hal tersebut mengarahkan Sara ke dalam masalah baru dan menciptakan hambatan baru; kemarahan adalah salah satu tindakkan frustasi yang selalu muncul sebagai akibat dari tindakanya.
\end{abstract}

Kata Kunci: Sara Fitzgerald, Konflik Internal, Konflik External.

\begin{abstract}
The main objective of this study is to investigate conflicts that Sara Fitzgerald has to undergo as depicted in a bestselling novel entitled My Sister's Keeper by Jodi Picoult. This study also aims to see how the conflicts develop

This study uses objective approach to help find the conflicts of Sara Fitzgerald and how her conflicts develop by applying the theory of internal and external conflict also the theory of frustration. The primary data used is the novel itself. The secondary data are the books related to the theory of conflict and articles from the internet.

The result of the study shows that there are four main problems that lead Sara Fitzgerald into conflicts. The problems are Sara having a baby, Jesse and Anna feeling neglected, the trial and Anna's death. The analysis shows that Sara decides to make important decisions for Kate's life. Sara faces many failures because of her decisions and it leads her to face more problems and creates new obstacles, one of which is Anger; this act of frustration always appears as the manifestation of her actions.
\end{abstract}

Keywords: Sara Fitzgerald, Internal Conflict, External Conflict. 


\section{INTRODUCTION}

My Sister's Keeper is one of New York Times Best Selling Novels written by Jody Picoult. Picoult came about the idea of her novel My Sister's Keeper when she knew about a couple in America that successfully conceived a sibling that was bone marrow match for his older sister; who suffers a rare form of leukemia. After that Picoult started to look more deeply at the family dynamics and how stem cell research might cause an impact. $M y$ Sister's Keeper is a novel with first person point of view but from lots of different perspectives. In My Sister's Keeper Jodi Picoult has masterfully covered yet another controversial topic and complicated conflicts that make this novel very interesting. It tells about a young Kate who is diagnosed with a severe form of leukemia. Her parents then have a baby, Anna, who is genetically selected to be a close donor match for Kate. From her birth onward into her early teens, Anna is called upon to undergo increasingly invasive and dangerous procedures to provide blood, bone marrow, and other tissues to sustain her older sister's life. Then, a kidney is needed, and Anna brings a lawsuit against her parents, claiming the right to her to make her own decision about what medical procedures can be performed on her. Anna's mother Sara, an attorney, decides to represent her own daughter Kate at the trial (Rieback: 2004). Sara Fitzgerald, one of the major characters in this novel, is chosen as the topic of analysis. Sara plays an important role in the conflict development of the story. Sara faces many conflicts since her daughter is diagnosed leukemia. Sara's desires for Anna to donor her kidney to her sister [Kate] makes Anna rebel against her. Paradoxically, by focusing so much on being a mother to Kate, Sara does not always fill the role of mother for her other children. Similarly, though Sara is a wife to Brian her relationship with Brian also revolves around Kate. Even with Kate, Sara focuses mostly on her physical, rather than emotional.

The approach used in this paper is objective approach. According to Abrams in his book The Mirror and the Lamp, Romantic Theory and the Critical Tradition:

But there is also a fourth procedure, the objective orientation, which on principle regards the work of art in isolation from all these external points of reference, analyzes it as a self-sufficient entity constituted by its parts in their internal relations, and sets out to judge it solely by criteria intrinsic to its own mode of being. (Abrams: 1977)

The present writer is going to analyze the character and the conflict of Sara Fitzgerald trough the plot. To support the analysis, it is important to have a better understanding of the theory on conflict itself. In literature, Conflict is the inherent incompatibility between the objectives of two or more characters or forces. By its nature, conflict is unstable. One side must always win and one side must always lose in the end. (http://en.wikipedia.org/ wiki/Conflict (narrative). In this case Sara Fitzgerald is a character that always wants to be a winner to defend her decision to save her daughter's life. To stand on her decision she has to face many problems that lead her to face many conflicts with other characters. To give a detail explanation, the present writer uses Stanton's theory which divides the types into internal and external conflict. Both theories will help the present writer to analyze the conflict that Sara Fitzgerald has to undergo.

To give more explanation how the conflict of Sara Fitzgerald develops, in this paper the writer tries to apply psychological theory, i.e. theory of frustration by Robert S. Woodworth and Ronald G. Marquis, to the main character in the story because of its great importance to this paper. The relationship between conflict and frustration is when the satisfaction of a motive is blocked by conflict, problem solving responses may be made. If 
this result in failure the individual may react emotionally. Frustration refers to the failure situation and the reactions it evokes.

In accordance with the discussion above, this article focuses on conflicts that Sara Fitzgerald has to undergo and the development of her conflicts. The explanations of conflicts faced by Sara Fitzgerald will be divided into four parts: (a) having a baby, (b) Jesse's and Anna's feeling of neglected, (c) the trial, and (d) Anna's death.

\section{HAVING A BABY}

The conflict of Sara Fitzgerald appears at the beginning of the story. Sara was initially thought by herself that being a lawyer was the best decision for her, but when she married Brian Fitzgerald and has children she changed her decision.

In my previous life, I was a civil attorney. At one point I truly believed that was what I wanted to be - but that was before I'd been handed fistful crushed violets from a toddler. I understood that the smile of a child is a tattoo: indelible art. (Picoult 2004:26)

Sara ultimately prefers to change her job from a lawyer to be a housewife. She is too in love with her child. In this case the way she reacts shows us that she struggles against her doubts which can be considers as an act of internal conflict.

The conflict of Sara Fitzgerald continues to a story when doctors diagnose Sara's twoyear-old daughter, Kate Fitzgerald, with a rare and aggressive form of leukemia. Kate suffers from Acute Promyelocytic Leukemia, a blood and bone marrow cancer. The news that their child might die shocks Sara and her firefighter husband, Brian Fitzgerald, but Sara immediately resolves to put Kate on treatment.

Kate starts chemotherapy, and her oncologist, Dr. Chance, suggests she might eventually need a bone marrow transplant, preferably from a related donor.
The Fitzgerald tests their four-year-old son, Jesse Fitzgerald, but he is not a match.

Dr. Chance mentions that another unborn sibling could be a match, and Sara suggests to Brian that they can have another child.

Sara faces an external conflict when she have been invited to a TV show because of her baby unorthodox conception. Nadya, the presenter of the TV show ask a question which makes Sara cannot hold emotion. It was a question about designer baby.

"We didn't ask for a baby with blue eyes, or one that would grow to be six feet tall, or one that would have an IQ of two hundreds. Sure, we asked for specific characteristic - but they're not anything anyone would ever consider to model human traits. They're just Kate's traits. We don't want a super baby; we just want to save our daughter's life. (Picoult 2004:100)

Some people think that her choice to have a baby is a bad decision and it causes her to receive a lot of hate mail because people think she makes a designer baby. She does not care about what people say about her decision. She keeps on her decision and she want to save the baby who will save her daughter's life. When someone faces a conflict sometimes to keep her decision she becomes stubborn. Stubbornness leads Sara to be someone who just thinks of herself and cares about what she wants to get. It shows when Nadya asks more question to her about the future of the unborn baby.

"Mrs Fitzgerald, what will you tell this baby when she grows up?" Nadya asks.

"With any luck," I say, "I'll be able to tell her to stop bugging her sister." (Picoult 2004:100)

The situation when Sara has to choose and decide something creates an internal conflict. Although there is not any explicit evidence on the novel, the present writer 
concludes that it must be hard for Sara to decide to have a new baby while many people blame her action to do it for Kate's life. The act when Sara has to keep and stand on her decision creates an external conflict between her and other character in the story. It shows when she has been invited to a TV Show. Sara cannot control her emotion when the presenter of the TV Show asks about designer baby. Her disagreement leads her to a debate between her and the TV Show presenter. Her action can be categorized as one of the external conflict types, Man vs. Society. Sara stands on her decision while most of people around her blame her decision. Sara becomes angry when someoneorothercharactertries to challenge her decision. Anger is the act of frustration and also the result when Sara's satisfaction is blocked by a conflict, and she finds a failure when she tries to solve her problem.

\section{JESSE'S AND ANNA'S FEELING OF BEING NEGLECTED}

Over the next few years, Anna undergoes several procedures, including frequent blood withdrawals and a painful bone marrow extraction, to help keep Kate alive.

However, it seems that Sara did pay too much attention to Kate to the point of emotionally neglecting her other children. Kate was always her first concern and she did not think much about that and considered it a given since Kate was dying. In different ways, both Jesse and Anna acted out at Sara because of her single-minded focus on Kate.

An external conflict of Sara Fitzgerald starts from when she tries to ignore her promise to Jesse to see the orthodontist and buy him new cleats, because then again Kate still be her first priority. Sara cancels the appointment and refuses to get new cleats for Jesse and says that is not a good time to go, but Sara tells it with anger.
"Your sister," I say evenly, "is incredibly sick. I'm sorry if that interferes with your dentist's appointment or your plan to go buy a pair of cleats. But those don't rate quite as high in the grand scheme of things right now. I'd think that since you're ten, you might be able to grow up enough to realize that the whole world doesn't always revolve around you." (Picoult 2004:162163)

As the result of her acts she understands that Jesse cannot be what she wants. She says her apology to Jesse but she gets a bad response.

\footnotetext{
"Now you never have to take me anywhere," he [Jesse] says. (Picoult 2004:163)
}

The act of apologizing that Sara does can be considered as the result of internal conflict. Sara realizes that she promises Jesse to buy him new cleats but again Sara has to decide between Kate's life and Jesse. It is hard for Sara when she has to face such a problem; She is always in a condition where she has to decide something to solve her problem and she manifests it by showing her anger to Jesse.

Another external conflict happens between Sara and Anna. Dr. Chance calls Sara that Kate needs ten thousands lymphocytes but Anna is in the middle of her friend's birthday party. Sara does not have any choice except picking Anna up from her friend's birthday party to the hospital, but Anna doesn't want to go.

Anna scowls, "Why did I[Anna] have to leave the party?". Because your sister is more important than cake and ice cream; because I cannot do this for her; because I said so. I'm so angry that I have to try twice before I can unlock the van. "Stop acting like a five-year-old," I accuse, and then I remember that's exactly what she is. (Picoult 2004:168)

From her conversation with Anna, it is found that when her satisfaction is blocked by conflict, she responds it with anxiety and anger. Sara feels worried for Kate's health and 
angry because Anna tries to refuse to go to the hospital.

Sara loves Kate so much. She does not want any bad thing to happen to her daughter, but the way she acts sometimes makes Anna's life uncomfortable. It happens when Anna is being invited to a Girl in Goal Summer Hockey Camp. Rather than supporting her daughter to attend the summer camp, Sara prefers not to give Anna permission because her heart says Kate's life is important than the summer camp.

"Honey", I say carefully, "You can't do this." She shakes her head, as if she's trying to make my words fit. "But it's not now, or anything. It's not till next summer." And Kate might be dead by then. (Picoult 2004:263)

Sara faces an internal conflict, Sara knows that the summer camp is important for Anna but Kate's life is more important. Sara knows that Anna will get mad at her and considers her as a bad mother for Anna. When Anna cannot fulfill the solution that Sara needs, Sara decides not to give Anna permission not because she is afraid of what might happens to Anna there but because she is afraid of what might happens to Kate when Anna is gone.

Until that point, going to Minnesota is not an option. Not because I am afraid of what might happen to Anna there, but because I am afraid of what might happen to Kate while her sister is gone. If Kate survives this latest relapse, who knows how long it will be before another crisis happens? And when it does, we will need Anna - her blood, her stem cells, her tissue right here. (Picoult 2004:263)

The external conflict happens because Anna cannot hold her emotion and Sara wants her to stay, but Sara does not tell the reason why. It blows up Anna's anger.

\footnotetext{
"I want to know why I can't go."

I run a hand down my face. "Anna, don't make me do this."
}

"Do what, Mom," she says hotly. "I don't make you do anything". (Picoult 2004:263)

In this part of the analysis several internal and external conflicts appear because Sara faces new problems. It shows that the more Kate suffers because of her illness, the more Anna has to donate everything what Kate needs. The more Kate feels sick, the more Sara neglects her two children; Jesse and Anna. Kate needs Anna to save her life and Sara does not repay it with affection; Sara prefers to think which part of Anna is important for Kate's life. It also tell, us that everytime a new problem comes another conflict happens and when Sara satisfaction is blocked by a conflict her way to express it is showing anger. Anger always comes out as a manifestation for Sara to end the conflict. The present writer concludes why Sara choose anger as the problem solving because Sara thinks that with anger she can resolve her problem or conflict that she faces.

\section{THE TRIAL}

As she grows older Anna realizes that something is not okay. She asks herself the purpose she lives in this world and then she realizes that she lives only to save her sister's life. It means that Anna must provide everything that her sister needs.

"The first time I gave something to my sister, it was cord blood, and I was a newborn. She has leukemia - APL - and my cells put her into remission. [...] I was five and I had lymphocytes drawn from me, [...] they took bone marrow for a transplant, [...] I had to donate granulocytes. [...] I had to donate peripheral blood stem cells" (Picoult 2004:20)

Anna goes to the office of Campbell Alexander, a lawyer, in order to hire him to sue her parents for the rights to her own body. The reason her parents had her in the first place, she explains, was so that she could donate bone marrow to her older sister, Kate. 
But over the years she has had to go through more and more surgeries. And now, her parents want her to donate a kidney to Kate, Anna has never had to donate a body organ before.

Once Campbell realizes that she is very serious about what she is doing, he agrees to be her lawyer.

Sara is shocked when she receives the legal papers informing them of what Anna is doing.

[...]. She unfolds the papers. I'm close to read them over her shoulder. THE STATE OF RHODE ISLAND AND PROVINCE PLANTATIONS, it say right across the top, official as can be. FAMILY COURT FOR PROVIDENCE COUNTY. IN RE: ANNA FITZGERALD, A.K.A.JANE DOE. PETITION FOR MEDICAL EMANCIPATION".(Picoult 2004:49)

An external conflict appears and the coming of the legal paper raises the anger of Sara Fitzgerald. She has no idea why Anna did that to her.

My[Anna] mother lifts her face to mine. "Anna," she whispers, "What the hell is this?”(Picoult 2004:50)

The conflict between Sara and Anna develops when Anna tries to explain that she does not want to do any surgeries. Anna wants to live normally like other girl. She wants to have a long life without any fears. I[Anna] duck my head. "I don't want to do it anymore." (Picoult 2004:52)

On the other side Sara defends her decision that her family has no other choice to save Kate's life but Anna thinks that she has the right to choose.

That ignites my[Anna] mother. "Well, you know Anna, neither do I[Sara]. In fact, neither, does Kate. But it's not something we have a choice about." (Picoult 2004:52)

The big fight between Sara and Anna continues because Sara thinks that Anna is being selfish to think just about herself. Sara simply disregards Anna's opinion because listening to Anna's desires meant letting her life to watch Kate die. She gave up her entire life to watch over Kate's health and she was not going to let anyone or anything ruin her battle. An external conflict appears as the result of her anger to Anna.

The thing is, I[Anna] do have a choice. Which is exactly why I have to be the one to do this.

My mother stands over me. "You[Anna] went to a lawyer and made him think this is all about you[Anna - and it's not. It's about us. All of us -." (Picoult 2004:52)

Brian who sees the big fight between Sarah and Anna try to make them calm. Anna is still on her decision to sue her parents and she talks to Brian that she will not do it anymore. Sara becomes angrier than before when she hears Anna does not change her decision.

"Daddy, [Anna]I can't."

"For God's sake, Anna," my[Anna] mother says. "Do you[Anna] even realize what the consequences would be?" (Picoult 2004:52)

Another external conflict happens between Sara and Jesse right after Anna and Sara came from Judge De Salvo's office. Sara who is in bad mood get angry because she thinks Anna's decision will send her sister to death and the result of her anger is Jesse feeling neglected.

Jesse turns off the television. "She made you[Anna] talk to a judge? Damn Anna"

My [Anna] mother closes her eyes. "Jesse, you know, now would be good time for you to leave."

"You [Sara] don't have to ask me [Jesse] twice," he says, his voice full of broken glass. We hear the front door open and shut, a whole story.

"Sara." My[Anna] father steps into the room. "We all need to cool off a little."

"I [Sara] have one child who's just signed her sister's death sentence, and I'm suppose to cool off?" (Picoult 2004:88-89) 
There is a misunderstanding between Sara and Anna that lead them to a new conflict. Sara and her husband agree that she need to listen to Anna a little bit and she thinks that Anna does not need a lawyer to solve their problem. First Anna thinks that her mother will allow her to stop donates her kidney but what is on Sara's mind is different. What Sara means is that Anna to stop her lawsuit and Anna reactions is still the same, she refuses it.

"When I said stop, I meant the lawsuit."

I shake my head hard, as much to give her an answer as to dislodge the knot of words tangled in my gut.

"My God Anna," my[Anna] mother says, stunned. "What have we done to you to deserve this?"

"It's not what you've done to me[Anna]."

"It's what we haven 't done, right?'

"You aren't listening to me!" I yell, and at that very moment, Vern Stackhouse walks up to our table. (Picoult 2004:176)

The misunderstanding between Sara and Anna can be categorized as an example of external conflict, Man VS Man. Sara always thinks about Kate's life and her mind is full of anger when someone tries to block her way to save Kate's life.

When Sara realizes that she is going to need a lawyer, Sara, who is a lawyer, decides to be the lawyer representing the opposing side. Since she was a successful lawyer and won most of her cases while in practice, she now sees Kate's disease as a case she must win as well. Since Sara won cases most of the time, she now feels she fight to keep Kate alive. She is not really believing the case will go far and thinking she will be able to talk Anna out of the suit. She thinks Anna is only doing this for attention.

Sara and Brian's marriage suffers as a result, to the point where they begin to feel like strangers. This situation leads Sara to face the external conflict with her husband. Sara wants a victory to win the trial so that she can save her daughter's life but when Sara needs someone to help her to face the problem, he prefer to be on Anna's side. Brian thinks that Anna has a right for her own life.

"Actually," I look down at my hands. "I'm going to speak on Anna's behalf."

"What?"

With a quick glance over my shoulder to make sure Kate is still sleeping, I do my best to explain. "Sara believe me, I've thought long and hard about this one. And if Anna's through being a donor for Kate, we've got to respect that." (Picoult 2004:254)

In this time Sara is in a frustrated condition. Sara feels disappointed and angry because Brian does not want to help her to convince Anna on the trial to help their older daughter, Kate. Sara cannot believe that her husband does this to her but then she does not realize that what she does to save Kate's life hurts Anna a lot. The fight between Sara and Brian makes her husband become a person who cannot stand at her side anymore.

To be fair, I am not the same man. The one who listened. The one who believed her. (Picoult 2004:254)

Throughout the trial, Sara realizes where she went wrong in some aspects of her parenting.

I am no lawyer, no professional. I have been nothing more than a mother, and I have not even done a very square job of that. (Picoult 2004:388)

Although there is not any explicit evidence of internal conflict in the novel based on the sentences above, the present writer concludes that Sara faces a hard time of being a mother.

Another proof that shows Sara faces a hard time being a mother is when she is on her capacity as a lawyer in a courtroom against her daughter, Anna. It shows when Sara answer Campbell's question. 
I take a deep breath. "In my life, though, that building was on fire, one of my children was in it - and the only opportunity to save her was to send in my other child, because she was the only one who knew the way. Did I know I was taking a risk? Of course. Did I realize it meant maybe losing both of them? Yes. Did I understand that may be it wasn't fair to ask her to do it? Absolutely. But also knew that it was the only chance I had to keep both of them. Was it legal? Was it moral? Was it crazy or foolish or cruel? I don't know. But I do know it was right." (Picoult 2004:390)

Sara's answer to Campbell question can be concluded that Sara will do everything which will be the best way to save Kate's life while someone will suffer as the result of saving Kate's life. From Sara's answer, although there is not any explicit evidence of internal conflict, the present writer concludes that from the illustration above Sara did face an internal conflict. In order to save Kate's life Sara pushes away her doubt, fear and worry about what might happens to Anna's life. What is on her mind everyday is how to save Kate's life because she thinks if Kate stay alive her family will be happy because Kate is not sick anymore. Her role as a lawyer makes her admit she has doubts, but her role as a mother leads her to say she would do anything to keep her family together.

Though Sara is frustrated at what Anna is doing, she never hates her or stops loving her.

"Anna," I tell her, "I love you. I loved you before I ever saw you, and I will love you long after I'm not here to say it. And I know that because I'm a parent, I'm supposed to have all the answer, but I don't. I wonder every single day if I'm doing the right thing. I wonder if I know my children the way I think I do. I wonder if I lose my perspective in being your mother, because I'm so busy being Kate's.'(Picoult 2004:388)

Based on the sentences above an example of internal conflict appears. The internal conflict appears when Sara realizes that she went wrong in some aspects of her parenting, then she realizes that she neglects Jesse and Anna. A mother is always the one to feel the deepest connection with her child, and that is why Sara was much more devoted to taking care of Kate. She confesses that she loves Anna but she realizes that she is busy with Kate. Sara loves her children. Anna was designed to save Kate, but Anna was not unloved. Anna may have been conceived this way; Sara never meant to just disregard her. The present writer thinks that Sara's life was just too hard, and she tried hard to be strong. She wanted to look strong for Kate, for Anna, for Jesse, and even for Brian but to do that she had to harden herself. She had to focus herself on one thing and that thing was making sure Kate got better. Sara thinks that the happiness of her family was linked to Kate's health. Sara thought she was doing this so that in the near future Kate would be cured and everyone would be happy. She never allowed herself to see that Kate being cured might never happen, and because of that she did not look up to acknowledge Anna and Jesse. The sentences above also can be concluded as the whole explicit evidence of the existence of the internal conflict of Sara Fitzgerald.

When facing a conflict, Sara needs a solution and the only solution that Sara pick is anger. The reason why anger is the only solution because Anna cannot fulfill the solution that is needed to save Kate's life. That is why Sara chooses to be angry to get what she wants because she has to decide something to solve her problem although the result is bad.

When Anna first finds out about the need for a kidney transplant, she was going to do it and had no problem with it. But, Kate convinces her not to donate it. Kate does not want to go through with the surgery, she was sick of it all. She realized she would die without the transplant, but she just could not go through it all. It was Kate who convinced Anna to get a 
lawyer but rather than believeing what Anna says, Sara prefers to believe that Anna misunderstands of what Kate said. Sara thinks that Kate faces a bad day when talking about it to Anna.

"May be you misunderstood. May be she was just having a bad day, or being dramatic." She smiles in the pained way of people who really want to cry. "Because if she was that upset, she would have told me."

"She couldn't tell you," I reply. "She was too afraid if she killed herself she'd be killing you, too." (Picoult 2004:373-374)

The external conflict between Anna and Sara shows a result that Sara only cares about Kate's health. Sara does not even realize Kate's feelings, Sara always decide everything based on her point of view and Kate's health. In this case, the internal conflict happens but it does not exist or there is not any explicit evidence in the novel but the present writer concludes that finally Sara realize that she went wrong to understand Kate. For so many times, Sara only cares about Kate's health without thinking of others, such as Anna's health.

The trial ends with the judge ruling in Anna's favor. She receives medical emancipation from her parents. Everyone is happy that the case is over, and no one is mad at Anna for doing what she did.

\section{ANNA'S DEATH}

A sad story happens at the end of the novel. On the way to the hospital, Campbell and Anna get into a serious car accident. The car is struck by a truck. Campbell is saved, but Anna is dead. Everyone is stricken with grief, especially Sara who had always been afraid of the death of her other daughter, Kate.

In the English language there are orphans and widows, but there is no word for the parents who lose a child. (Picoult 2004:401)

I sit down on the edge of the bed and pick up Anna's hand, still warm to the touch, still soft inside mine. It turns out that after all these years
I have spent anticipating a moment like this, I am completely at a loss. Like coloring the sky in with crayon; there is no language for grief this big. "I can't do this," I whisper. (Picoult 2004:401)

Sara is in a big depression, she loses Anna forever in her life. She realizes that her choices makes Anna feels neglected, but what makes Sara feels more frustrated is when she knows that Anna donates everything in her body to save Kate's life.

\section{CONCLUSION}

Both the theory of internal and external conflict explains how the conflict of Sara Fitzgerald grows. An internal conflict means that Sara has to struggle against her doubts or feeling. In this case when Sara needs to decide something to make an important choice but some of her decisions to save Kate's life makes her life becomes worse. It is hard to find the explicit evidence of internal conflict of Sara Fitzgerald in the novel because she prefers to push away her doubts, fears and worry. Anger is chosen as the manifestation because there is not any possible solution for her when she needs to solve her problem. But an evidence of internal conflict shows at the end of the story when Sara admits that she loves Anna but she is busy with Kate. From her confession, the present writer concludes that Sara regrets because she has done wrong as a mother. External conflict is a conflict when a character struggles with an outside force or problem. Sara comes to a big fight with her children because Sara always thinks about Kate's health. The conflict again develops when Anna realizes that her life is more important rather than just giving everything that Kate's need. She sues Sara and wants a right for her own body. Sara cannot believe that Anna will do this to her. When she receives the legal paper from the court she defends herself and acts as a lawyer. Everytime she meets Anna she always convinces her to save Kate's life by donating a 
kidney for her sister but Anna refuses it. Sara is frustrated with her life and becomes angry to everyone even with her husband. The conflict stops when Anna wins the trial and climax comes when Anna dies in a car accident.

\section{BIBLIOGRAPHY}

Abrams, MH. The Mirror and the Lamp, Romantic Theory and the Critical Tradition. USA: Oxford University Press. 1977

Picoult, Jodi. My Sister's Keeper. London: Hodder and Stoughton, Ltd. 2004.
Rieback, Eileen. 2004. Complex Issues in A Fascinat ingStory. $<$ http://www.amazon.com/review/R1W4B SITSLE407/ref $=\mathrm{cm}$ cr dp title/180-82366175497168? ie $=$ UTF 8 A ASIN $=0743454529 \&$ nodeID $=283155 \&$ store $=$ books $>$. (Accessed May 2012)

Woodworth, Robert S. and Ronald D. Marquis. Psychology. United States of America: Henry Holt and Company, Inc. 1957.

http://en.wikipedia.org/wiki/Conflict_(narrative) (Accessed February 13th 2012) 